\title{
Toxicity of UV filters on marine bacteria: Combined effects with damaging solar radiation
}

\author{
Clément Lozano ${ }^{\mathrm{a}, \mathrm{b}}$, Sabine Matallana-Surget ${ }^{\mathrm{b}, *}$, Justina Givens ${ }^{\mathrm{a}}$, Salomé Nouet ${ }^{\mathrm{a}}$, Louise Arbuckle ${ }^{\mathrm{b}}$, \\ Zacharie Lambert ${ }^{a}$, Philippe Lebaron ${ }^{\mathrm{a}, *}$ \\ a Sorbonne Université, CNRS, Laboratoire de Biodiversité et Biotechnologies Microbiennes, USR3579, Observatoire Océanologique, 66650 Banyuls-sur-mer, France \\ b Division of Biological and Environmental Sciences, Faculty of Natural Sciences, Stirling University, United Kingdom
}

\section{H I G H L I G H T S}

- Five organic UV filters were tested for the first time on 27 marine bacteria.

- Seven bacteria demonstrated sensitivity against at least one UV filter.

- Octinoxate is the most toxic UV filter, affecting 5 out of 7 sensitive species.

- The physiological state plays a key role in the bacterial sensitivity to UV-filters.

- Solar radiation modulates UV filters toxicity.

\section{G R A P H I C A L A B S T R AC T}

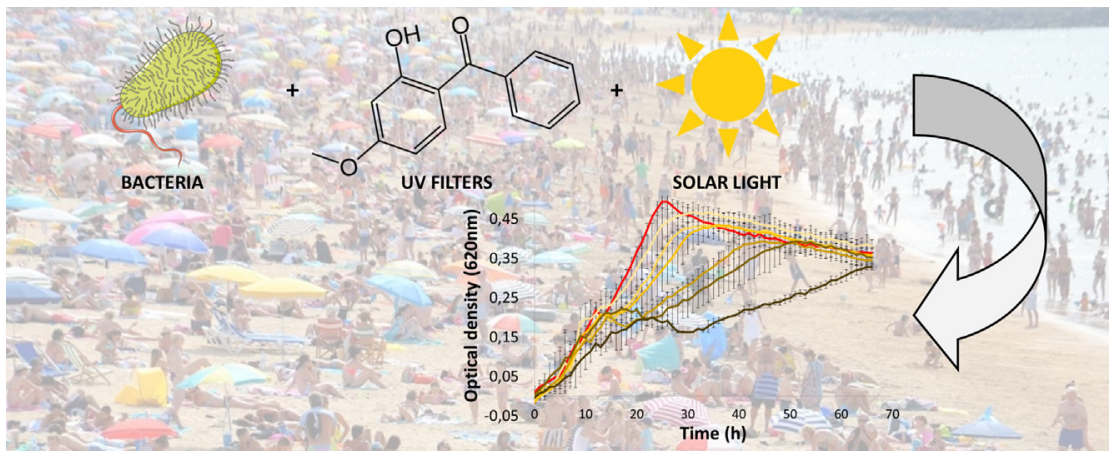

\section{A R T I C L E I N F O}

\section{Article history:}

Received 3 February 2020

Received in revised form 6 March 2020

Accepted 6 March 2020

Available online 07 March 2020

Editor: Damia Barcelo

\section{Keywords:}

UV filters

Microbial ecotoxicology

Phototoxicity

Marine bacteria

\begin{abstract}
A B S T R A C T
Organic UV filters are of emerging concern due to their occurrence and persistence in coastal ecosystems. Because marine bacteria are crucial in the major biogeochemical cycles, there is an urgent need to understand to what extent these microorganisms are affected by those chemicals. This study deciphers the impact of five common sunscreen UV filters on twenty-seven marine bacteria, combining both photobiology and toxicity analysis on environmentally relevant species. Seven bacteria were sensitive to different organic UV filters at $1000 \mu \mathrm{g} \mathrm{L}{ }^{-1}$, including octinoxate and oxybenzone. This is the first report demonstrating inhibition of bacterial growth from $100 \mu \mathrm{g} \mathrm{L}^{-1}$. None of the UV filters showed any toxicity at $1000 \mu \mathrm{g} \mathrm{L}{ }^{-1}$ on stationary phase cells, demonstrating that physiological state was found to be a key parameter in the bacterial response to UV-filters. Indeed, nongrowing bacteria were resistant to UV filters whereas growing cells exhibited UV filter dependent sensitivity. Octinoxate was the most toxic chemical at $1000 \mu \mathrm{g} \mathrm{L} \mathrm{L}^{-1}$ on growing cells. Interestingly, photobiology experiments revealed that the toxicity of octinoxate and homosalate decreased after light exposure while the other compounds were not affected. In terms of environmental risk characterization, our results revealed that the increasing use of sun blockers could have detrimental impacts on bacterioplanktonic communities in coastal areas. Our findings contribute to a better understanding of the impact of the most common UV filters on bacterial species and corroborate the importance to consider environmental parameters such as solar radiation in ecotoxicology studies.

Crown Copyright @ 2020 Published by Elsevier B.V. This is an open access article under the CC BY license (http:// creativecommons.org/licenses/by/4.0/).
\end{abstract}

\footnotetext{
* Corresponding authors.

E-mail addresses: sabine.matallanasurget@stir.ac.uk (S. Matallana-Surget), philippe.lebaron@obs-banyuls.fr (P. Lebaron).
} 


\section{Introduction}

Organic UV filters are chemicals that absorb UVB (280-315 nm) and/ or UVA (315-400 nm) (Shaath, 2010). Due to their absorbing properties, UV filters are the main components of sunscreen, and are also found in industrial products such as paints and plastics as stabilizing agents. UV filters are of emerging concern due to their large production volumes, the increasing coastal tourism, their persistence related to their chemical properties, and their toxicity (Raineri et al., 2017). Previous studies reported the occurrence of UV filters ranging from nano to microgram per liter in different biotopes (rivers (Kameda et al., 2011; Fent et al., 2010), lakes (Balmer et al., 2005; Fagervold et al., 2019; Langford et al., 2015), coastal waters (Fagervold et al., 2019; TovarSánchez et al., 2013; Apel et al., 2018; Sánchez Rodríguez et al., 2015; Tsui et al., 2019; Sankoda et al., 2015) and sediments (Kameda et al., 2011; Fagervold et al., 2019; Mitchelmore et al., 2019)) but also demonstrated their bioaccumulation and toxic effects on several aquatic organisms (algae (Mao et al., 2018; Seoane et al., 2017), coral (Mitchelmore et al., 2019; He et al., 2019; Tsui et al., 2017), benthic mollusks (Giraldo, 2017), fishes (Araújo et al., 2018), dolphin(Alonso et al., 2015; Gago-Ferrero et al., 2013)), considering a wide variety of toxicological endpoints. Organic UV filters showed variable photostability. While benzophenone-3 (BP3), octocrylene (OC) and 4methylbenzilidene camphor (4-MBC) were described as photostable (Rodil et al., 2009; Herzog et al., 2009; Liu et al., 2011), cinnamate and triazone derivatives were found to produce photoproducts (Jentzsch et al., 2016; MacManus-Spencer et al., 2011; Damiani et al., 2010) and their toxicity is yet to be explored.

While many publications emphasized the detrimental impact of UV filters on our Oceans, until now, there has been a limited number of studies addressing the toxicity of those emerging pollutants on microorganisms. Marine bacteria are dominant organisms on Earth and play a vital role in marine ecosystems (Bar-On et al., 2018; Whitman et al., 1998). In addition, they are symbiotic partners of multiple organisms such as coral (Reshef et al., 2006), sea weed (Egan et al., 2013), algae (Ramanan et al., 2016) and sponge (Lee et al., 2001). Only a limited number of studies have reported the toxicity of oxybenzone on bacteria. A decrease in chl-a content and an elevation of carotenoid production have been reported for Microcystis aeruginosa (Mao et al., 2017) Zhang et al. (2017) showed that benzophenone derivatives inhibit the growth
Table 2

List of bacterial strains used in this study.

\begin{tabular}{llc}
\hline Phyla & Bacterial species & BBCC number \\
\hline Actinobacteria & Arthrobacter aurescens & 172 \\
Actinobacteria & Brachybacterium sacelli & 164 \\
Actinobacteria & Dietzia maris & 167 \\
Bacteroitedes & Algoriphagus mannitolivorans & 266 \\
Bacteroitedes & Algoriphagus ornithinivorans & 48 \\
Bacteroitedes & Maribacter dokdoensis & 57 \\
Bacteroitedes & Olleya marilimosa & 14 \\
Bacteroitedes & Sabulilitoribacter multivorans & 185 \\
Firmicutes & Bacillus megaterium & 240 \\
Firmicutes & Halobacillus dabanensis & 119 \\
Firmicutes & Paenibacillus glucanolyticus & 237 \\
$\alpha$-Proteobacteria & Epibacterium mobile & 367 \\
$\alpha$-Proteobacteria & Erythrobacter citreus & 2 \\
$\alpha$-Proteobacteria & Erythrobacter nanhaisediminis & 234 \\
$\alpha$-Proteobacteria & Paracoccus hibiscisoli & 192 \\
$\alpha$-Proteobacteria & Pelagibacterium halotolerans & 52 \\
$\alpha$-Proteobacteria & Phaeobacter inhibens & 654 \\
$\alpha$-Proteobacteria & Pseudoalteromonas agarivorans & 182 \\
$\gamma$-Proteobacteria & Alteromonas genovensis & 151 \\
$\gamma$-Proteobacteria & Alteromonas marina & 54 \\
$\gamma$-Proteobacteria & Enterovibrio calviensis & 113 \\
$\gamma$-Proteobacteria & Paraglaciecola mesophila & 6 \\
$\gamma$-Proteobacteria & Pseudoalteromonas hodoensis & 177 \\
$\gamma$-Proteobacteria & Pseudomonas kunmingensis & 268 \\
$\gamma$-Proteobacteria & Rheinheimera baltica & 75 \\
$\gamma$-Proteobacteria & Vibrio aestuarianus & 280 \\
$\gamma$-Proteobacteria & Vibrio azureus & 222 \\
\hline
\end{tabular}

of Vibrio fischeri. The authors observed a linear relationship between the $\operatorname{LogK}_{\mathrm{ow}}$ and the toxicity of the UV filter. Similarly, the toxicity of benzophenones on Photobacterium phosphoreum was shown to be correlated with their polarity (Liu et al., 2015). Therefore, there is an urgent need to understand to what extent marine bacteria are affected by those chemicals.

Our study investigates for the first time the toxicity of commonly used UV filters, namely BP3, OC, 4-MBC, EHMC and homosalate (HS) on marine heterotrophic bacteria, sampled from the Mediterranean Sea (Banyuls sur Mer, France). For this purpose, twenty-seven environmentally relevant bacteria, were tested for their response against the above-mentioned compounds. Furthermore, dose response analysis

Table 1

Physiochemical properties of tested UV filters.

\begin{tabular}{|c|c|c|c|c|}
\hline Name & $\operatorname{CAS} n^{\circ}$ & Structure & Molecular weight & Log Kow \\
\hline Benzophenone-3 (BP3) & $131-57-7$ & & 228.243 & 3.52 \\
\hline Ethylhexyl methoxy cinnamate (EHMC) & $5466-77-3$ & & 290.397 & 5.80 \\
\hline Octocrylene (OC) & $6197-30-4$ & & 361.477 & 6.88 \\
\hline 4-Methyl benzylidene camphor (4-MBC) & $36861-47-9$ & & 254.367 & 5.92 \\
\hline Homosalate (HS) & $118-56-9$ & & 262.344 & 6.16 \\
\hline
\end{tabular}


was carried out for sensitive strains, in order to better understand the range of UV filters toxicity. Interestingly, UV filters toxicity can also be modulated by other key intrinsic or extrinsic parameters that must be taken into account. For instance, both the physiological state (Jaishankar and Srivastava, 2017; Eng et al., 1991) and sunlight can alter the bacterial susceptibility to bactericidal compounds and anthropogenic contaminants (Sakkas et al., 2009; Petersen et al., 2008; Pelletier et al., 1997). Therefore, we also aimed at assessing the bacterial response to UV filters, harvested at both exponential and stationary phases and combined with solar radiation exposure. Overall, this paper presents a comprehensive investigation of the impact of five common UV filters on diverse marine bacterial species, spanning a range of different cellular parameters and UV exposure.

\section{Materials and methods}

\subsection{Chemicals}

Five organic UV filters, namely, benzophenone-3 (CAS-No. 131-577), ethylexyl methoxy cinnamate (CAS-No. 5466-77-3), octocrylene
(CAS-No. 6197-30-4), 4-methylbenzylidene camphor (CAS-No 3686147-9) and homosalate (CAS-No 118-56-9), were purchased from Sigma-Aldrich (Steinheim, Germany) (Table 1). Stock solutions of UV filters were dissolved in dimethyl sulfoxide (DMSO, Sigma-Aldrich, purity $>99 \%$ ) at a concentration of $750 \mathrm{mg} \mathrm{L}^{-1}$ and stored in the dark at room temperature.

\subsection{Bacterial strains}

A total of 27 bacterial strains from the Banyuls Bacterial Culture Collection (BBCC, https://collection.obs-banyuls.fr/catalogue.php) was used in this study (Table 2). Species were selected to ensure environmentally relevant diversity. Bacterial strains were kept at $-80^{\circ} \mathrm{C}$ in marine broth 2216 (DIFCO, United States) with 35\% glycerol. Bacteria were grown on marine agar plates. After $24-48 \mathrm{~h}$ incubation, colonies were suspended and grown aerobically on a rotary shaker $(110 \mathrm{rpm})$ at $25^{\circ} \mathrm{C}$ in artificial seawater with $3 \mathrm{mM}$ D-glucose, vitamins, and trace elements (ASW-G) (Eguchi et al., 1996). Cultures were performed in triplicates.
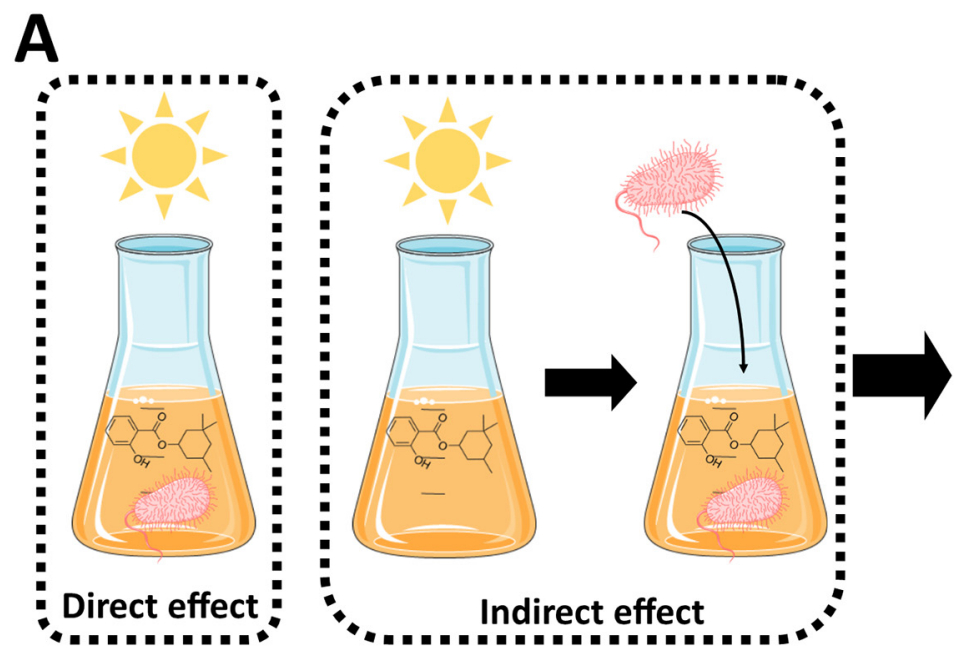

\section{Bacterial growth monitoring}
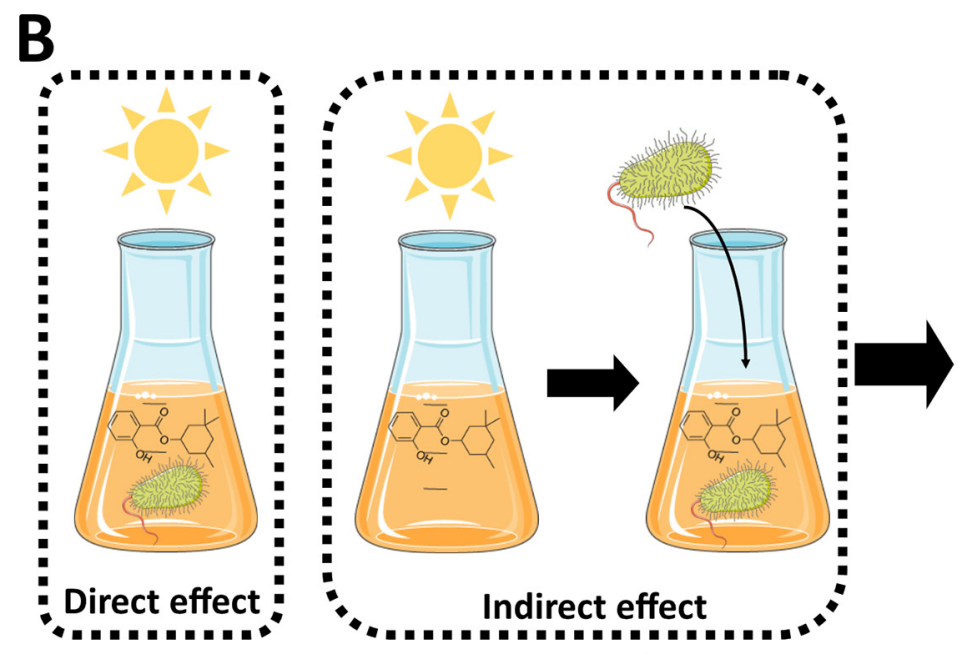

\section{Bacterial viability monitoring}

Exponential phase bacteria

Artificial solar light

Stationary phase bacteria

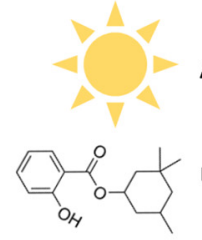

UV filter 


\subsection{Toxicity of UV filters}

The response of 27 bacterial strains (Table 2) against UV filters ( $\left.1000 \mu \mathrm{g} \mathrm{L}^{-1}\right)$ was assessed in minimum growth medium ASW-G. Bacterial growth was monitored in a 24 well plate during $48 \mathrm{~h}$ using a microplate reader (Paradigm, Molecular Device, United States) in presence of UV filters, with $1 \%$ of DMSO, to enhance the UV filters solubility. UV filters free and DMSO free controls were performed.

\subsection{Dose response on bacterial growth}

Dose response was further investigated for strains that showed sensitivity to UV filters at $1000 \mu \mathrm{g} \mathrm{L}{ }^{-1}$. The tested concentrations of UV filters were the following: $0,100,200,500,1000,2000$ and $4000 \mu \mathrm{g} \mathrm{L}^{-1}$, in ASW-G with $1 \%$ DMSO.

\subsection{Combined effect of UV filter and solar radiation}

The combined effect of solar radiation and UV filter was assessed on sensitive strains. Exposure to artificial solar light was performed using Oriel (United States) solar simulator, equipped with Hg 1600 W sunlight full spectrum lamp (280-800 nm).

The toxicity of the irradiated and non-irradiated UV filters was assessed on bacteria in stationary phase and exponential phase (Fig. 1). Stationary phase cells were maintained in ASW while growing cells were cultivated in ASW-G (supplemented with $3 \mathrm{mM}$ D-glucose, trace metals and vitamins). Solar radiation exposure was performed in quartz flasks.

\subsubsection{Effect of irradiated UV filters on stationary phase culture}

Bacteria were cultured in ASW-G, until stationary phase was reached. Cultures were centrifuged for $10 \mathrm{~min}$ at $3000 \mathrm{~g}$ and the cell pellets were washed in ASW to remove traces of carbon source. Cells were suspended in ASW with $1000 \mu \mathrm{g} \mathrm{L}^{-1}$ UV filters, pre-irradiated for $5 \mathrm{~h}$ under solar light. Non irradiated molecule and UV filters free medium were used as controls. Flasks were incubated and plated for CFU counting after 0,5 and $24 \mathrm{~h}$ of incubation at $25^{\circ} \mathrm{C}$.

\subsubsection{Effect of irradiated UV filters on exponential phase culture}

UV filters ( $\left.1000 \mu \mathrm{g} \mathrm{L}^{-1}\right)$ in ASW were exposed to artificial solar radiation for $5 \mathrm{~h}$. It is noteworthy to mention that vitamins and glucose were added after exposure to solar radiation in order to prevent UV-induced photoproducts from the growth medium's components. Media were inoculated with fresh precultures and the optical density (OD) at $620 \mathrm{~nm}$ was monitored from 48 to $72 \mathrm{~h}$. Non-irradiated medium and UV filters free medium were used as controls.

\subsubsection{Direct effect of solar radiation and UV filters on stationary phase culture}

Stationary phase cultures were prepared as described in 2.5.1. Bacteria were submitted to four treatments: (1) ASW + UV filters $1000 \mu \mathrm{g} \mathrm{L}^{-1}$ in dark condition, (2) ASW + UV filters $1000 \mu \mathrm{g} \mathrm{L}^{-1} \mathrm{ex}-$ posed to artificial solar light, (3) ASW in dark condition, (4) ASW exposed to artificial solar radiation. Plating for CFU counting was performed after $0,2.5$ and $5 \mathrm{~h}$ of exposure to the different treatments.

Table 3

Sensitivity of marine bacteria to different UV filters at $1000 \mu \mathrm{g} \mathrm{L}{ }^{-1}$. Black colored cells represent toxic UV filters, inducing bacterial growth inhibition.

\begin{tabular}{|c|c|c|c|c|c|c|c|}
\hline Phyla & Species & BBCC number & BP3 & EHMC & OC & 4MBC & HS \\
\hline Actinobacteria & Arthrobacter aurescens & 172 & & & & & \\
\hline Actinobacteria & Brachybacterium sacelli & 164 & & & & & \\
\hline Actinobacteria & Dietzia maris & 167 & & & & & \\
\hline Bacteroitedes & Algoriphagus mannitolivorans & 266 & & & & & \\
\hline Bacteroitedes & Algoriphagus ornithinivorans & 48 & & & & & \\
\hline Bacteroitedes & Maribacter dokdoensis & 57 & & & & & \\
\hline Bacteroitedes & Olleya marilimosa & 14 & & & & & \\
\hline Bacteroitedes & Sabulilitoribacter multivorans & 185 & & & & & \\
\hline Firmicutes & Bacillus megaterium & 240 & & & & & \\
\hline Firmicutes & Halobacillus dabanensis & 119 & & & & & \\
\hline Firmicutes & Paenibacillus glucanolyticus & 237 & & & & & \\
\hline$\alpha$-proteobacteria & Epibacterium mobile & 367 & & & & & \\
\hline$\alpha$-proteobacteria & Erythrobacter citreus & 2 & & & & & \\
\hline$\alpha$-proteobacteria & Erythrobacter nanhaisediminis & 234 & & & & & \\
\hline$\alpha$-proteobacteria & Paracoccus hibiscisoli & 192 & & & & & \\
\hline$\alpha$-proteobacteria & Pelagibacterium halotolerans & 52 & & & & & \\
\hline$\alpha$-proteobacteria & Phaeobacter inhibens & 654 & & & & & \\
\hline$\alpha$-proteobacteria & Pseudoalteromonas agarivorans & 182 & & & & & \\
\hline V-proteobacteria & Alteromonas genovensis & 151 & & & & & \\
\hline v-proteobacteria & Alteromonas marina & 54 & & & & & \\
\hline v-proteobacteria & Enterovibrio calviensis & 113 & & & & & \\
\hline V-proteobacteria & Paraglaciecola mesophila & 6 & & & & & \\
\hline v-proteobacteria & Pseudoalteromonas hodoensis & 177 & & & & & \\
\hline v-proteobacteria & Pseudomonas kunmingensis & 268 & & & & & \\
\hline V-proteobacteria & Rheinheimera baltica & 75 & & & & & \\
\hline v-proteobacteria & Vibrio aestuarianus & 280 & & & & & \\
\hline V-proteobacteria & Vibrio azureus & 222 & & & & & \\
\hline
\end{tabular}



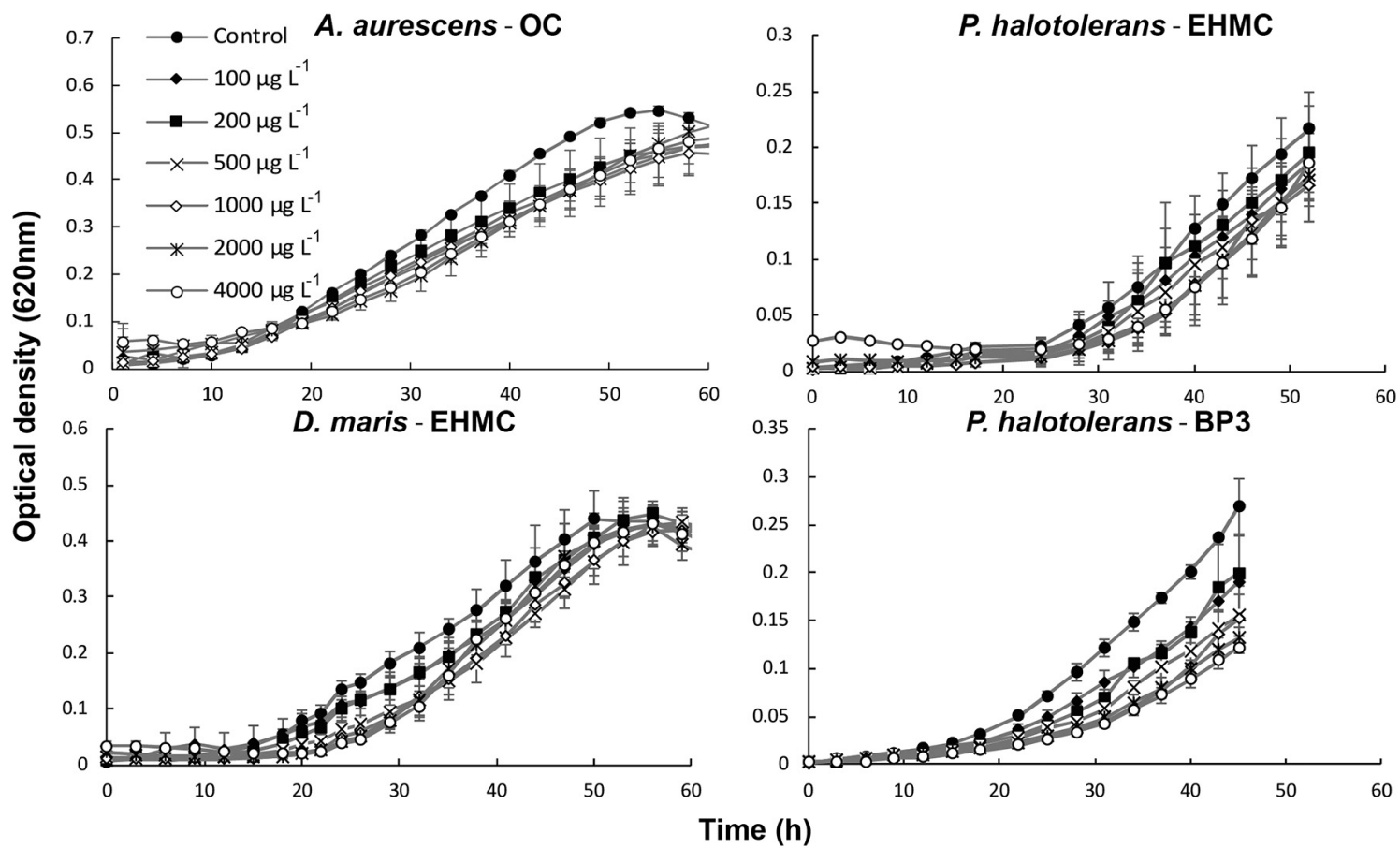

Fig. 2. Bacterial growth curves with different concentrations of UV filters. Only species that showed non monotonic response were presented (average \pm standard deviation, $n=3$ ).
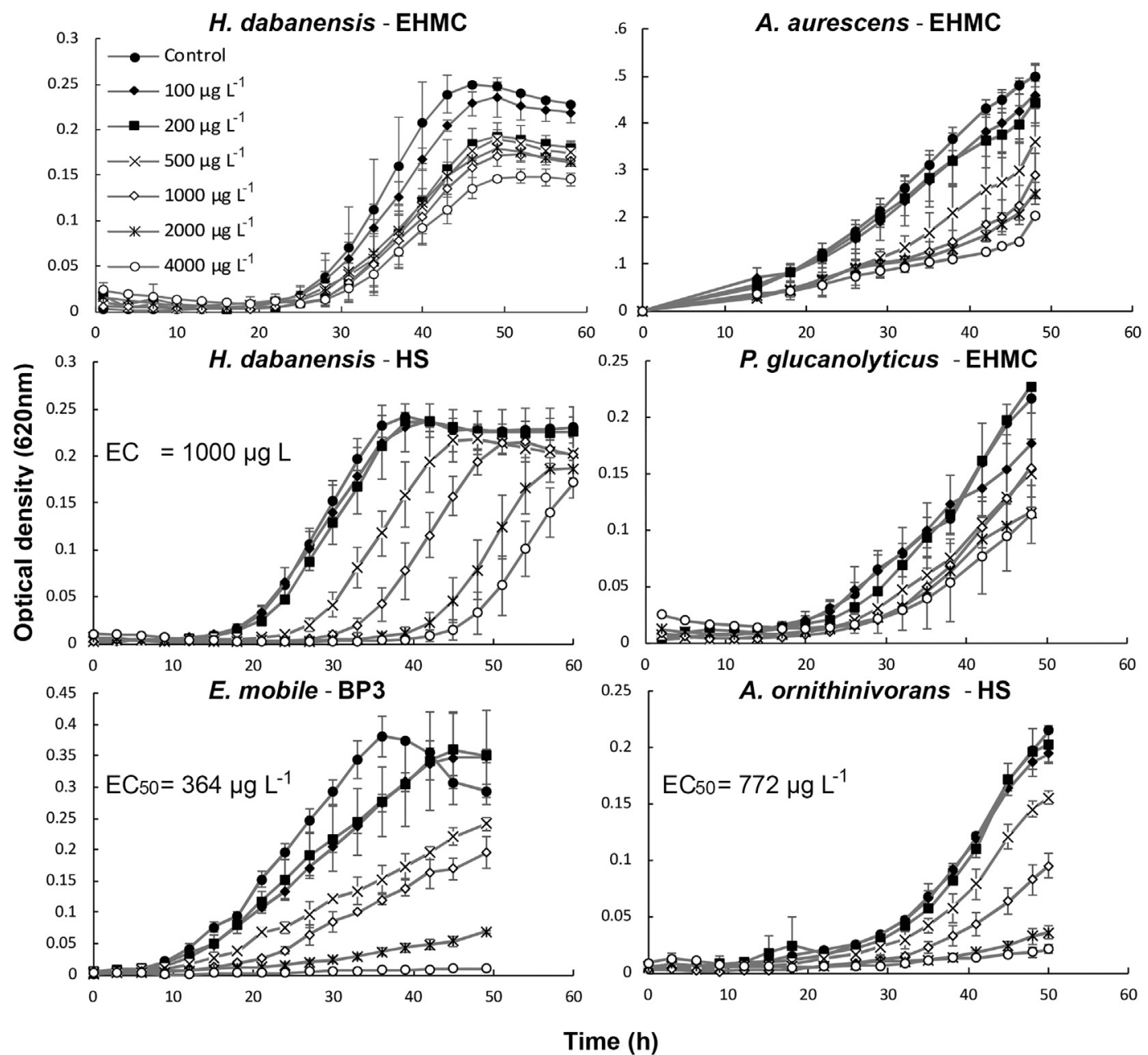

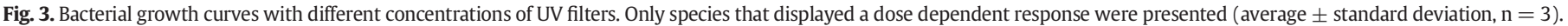


2.5.4. Direct effect solar radiation and UV filters on exponential phase culture

Bacterial cultures were grown in Erlenmeyer flasks. Bacteria were harvested at an OD $(620 \mathrm{~nm})$ of 0.15 and subsequently transferred into quartz flasks. Bacteria were subjected to four treatments: (1) ASW + UV filters $1000 \mu \mathrm{g} \mathrm{L}{ }^{-1}$ in dark condition; (2) ASW + UV filters $1000 \mu \mathrm{g} \mathrm{L}^{-1}+$ solar radiation; (3) ASW in dark condition; (4) ASW + solar radiation. OD (620 nm) was monitored for $5 \mathrm{~h}$.

\subsection{Statistical analysis}

All experiments were performed in triplicate. The normality of the data was verified using Kolmogorov-Smirnov test. One-way analysis of variance (ANOVA) and post-hoc Tukey HSD tests were used to assess the significance of the toxicity between different treatments ( $p$ value $<.05)$.

\section{Results and discussion}

Our study addressed for the first time, the combined impact of five common UV filters with solar radiation on diverse marine bacteria. In addition to the well-studied UV filters such as octinoxate, oxybenzone, and octocrylene, we provided the original toxicity assessment of homosalate on marine organisms.

\subsection{Toxicity of UV filters}

We first analyzed the bacterial response to UV filters at a concentration of $1000 \mu \mathrm{g} \mathrm{L}-1$. For this purpose, we studied a diversity of bacteria from different Phyla, a panel composed of nine $\gamma$-Proteobacteria, seven $\alpha$-Proteobacteria, five Bacteroidetes, three Actinobacteria, and three Firmicutes. A total of 7 out of 27 bacterial species showed a sensitivity to one, or more UV filters at $1000 \mu \mathrm{g} \mathrm{L}^{-1}$, representing $26 \%$ of all tested bacteria (Table 3). OC was toxic to one species. BP3 and HS were deleterious to two species and EHMC was the most toxic affecting five bacterial species. Although 4-MBC toxicity was previously reported (Sieratowicz et al., 2011; Torres et al., 2016; Campos et al., 2017), no sensitivity was observed in this study. It is interesting to note that BP3 only affected gram negative species (Bacteroidetes and Proteobacteria), while EHMC and HS showed toxicity against both gram negative and gram positive bacteria (Actinobacteria and Firmicutes), thus suggesting that UV filters could target different membrane structures according to their physicochemical properties. As previously demonstrated with antibiotics, bactericidal compounds can alter multiple cellular processes, such as DNA replication, by targeting DNA gyrase(Lewin et al., 1991),

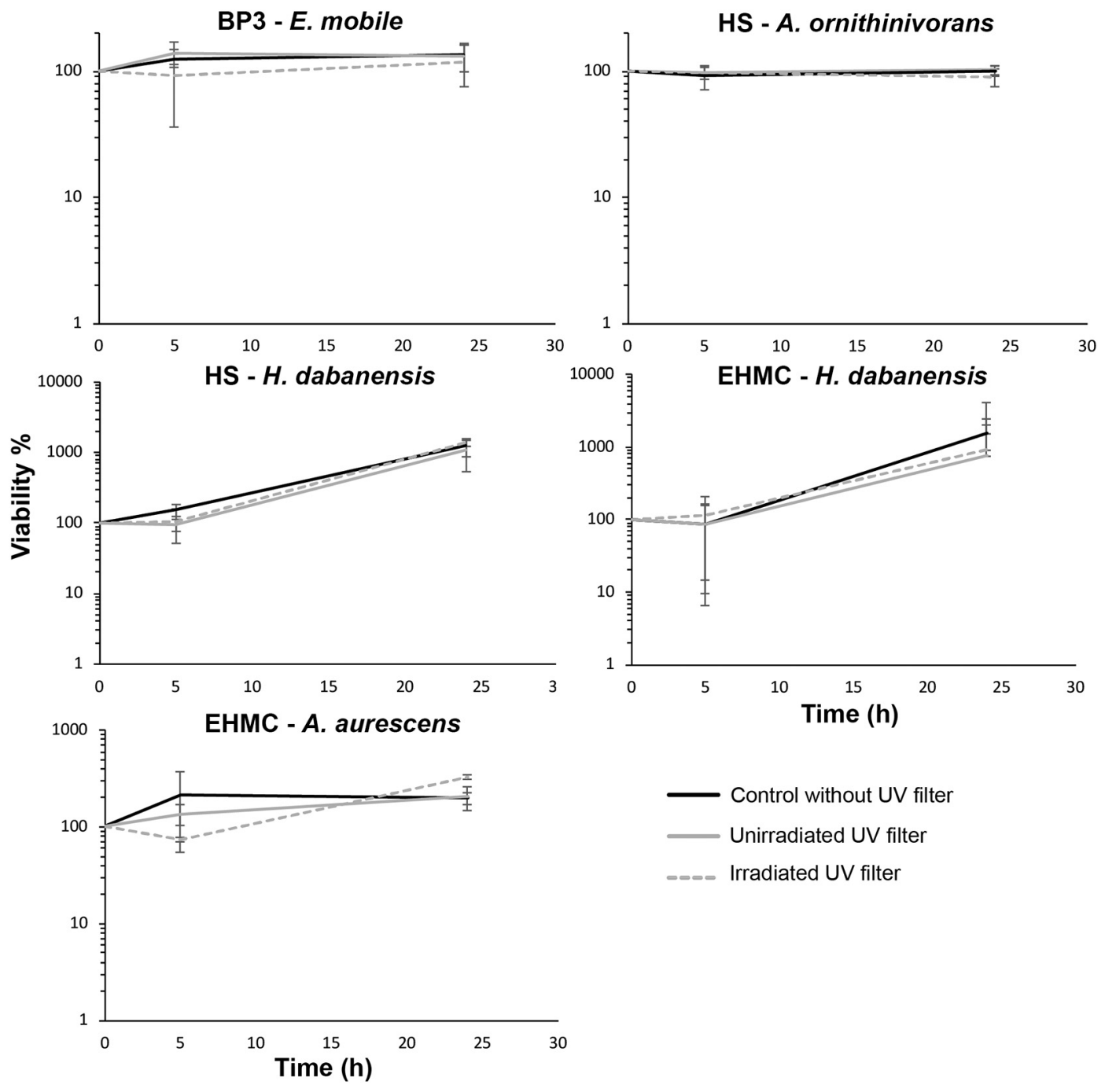

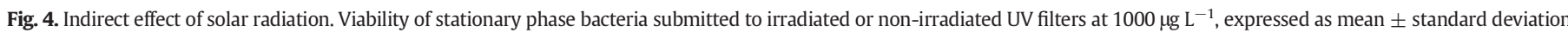
$(n=3)$. 
membrane synthesis, by interfering in the lipid organization of the cell membrane(Müller et al., 2016), or protein synthesis, through binding to ribosomal subunits (Greulich et al., 2015). Therefore, if we hypothesized that UV filters altered the above-mentioned mechanisms, further investigation would be needed to confirm these hypotheses.

Proteobacteria are the most abundant class as they can reach $50 \%$ abundance in coastal ecosystem (Coclet et al., 2019). They support multiple functions such as nitrate reduction, denitrification and carbon fixation (Yilmaz et al., 2016). Among all proteobacteria tested, none of the $\gamma$-proteobacteria was sensitive to any UV filter and 2 out of $7 \alpha$ proteobacteria were sensitive to BP3, including Epibacterium mobile, from the Roseobacter clade. Bacteria from the Roseobacter clade account for $20 \%$ of bacterioplanktonic communities in coastal waters (Buchan and Moran, 2005), and display versatile metabolic activities (Azam and Malfatti, 2007). Bacteroidetes are the second most abundant phyla (Coclet et al., 2019) and play an important role in denitrification and organic carbon degradation (Yilmaz et al., 2016). Algoriphagus ornithivorans was the only one out of five Bacteroidetes to be reported as sensitive to HS. Actinobacteria are involved in phosphate uptake and the degradation of cellulose, hemicellulose and chitin (Yilmaz et al., 2016). Within this phylum, Arthrobacter species are known to degrade PAH (Sawulski et al., 2014), polyethelyene (Balasubramanian et al., 2010), and metabolize pesticide (Kundu et al., 2019). The growth of two out of three Actinobacteria, including one Arthrobacter species, was altered by UV filters. Lastly, similar trends were observed for Firmicutes that are often found in the gut of marine invertebrates ( $\mathrm{Li}$
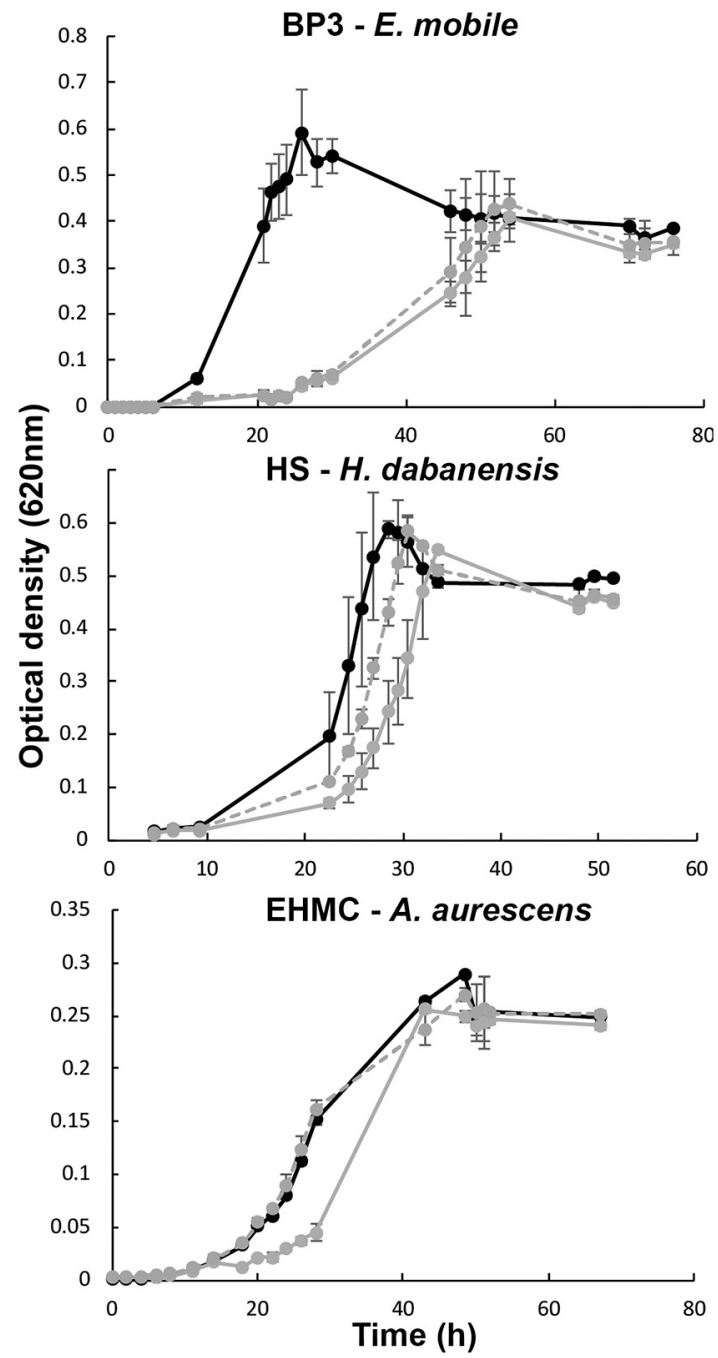

et al., 2018). Taken together, these results suggest that the studied UV filters might affect the growth of key players within coastal microbial communities where UV filters can reach high concentrations (Kim and Choi, 2014; Tsui et al., 2014; Downs et al., 2016).

\subsection{Dose response on bacterial growth}

Bacteria showing a sensitivity to UV filters at $1000 \mu \mathrm{g} \mathrm{L}{ }^{-1}$, colored in black in Table 3, were further studied for their dose responses with concentrations ranging from 100 to $4000 \mu \mathrm{g} \mathrm{L}^{-1}$. The dose response of seven bacteria to different UV filters was tested as follows: Arthrobacter aurescens (BBCC 172) against EHMC and OC; Algoriphagus ornithinivorans (BBCC 48) against HS; Dietzia maris (BBCC 167) against EHMC; Epibacterium mobile (BBCC 367) against BP3; Halobacillus dabanensis (BBCC 119) against HS and EHMC; Paenibacillus glucanolyticus (BBCC 237) against EHMC and Pelagibacterium halotolerans (BBCC 52) against BP3 and EHMC (Figs. 2 and 3). We observed different profiles of dose responses. Some strains showed a non-monotonic dose response, which means that the observed inhibition of growth did not increased as we increased the compounds concentrations (Fig. 2). Monotonic and non-monotonic responses were observed for the same given compound, showing the response was species specific.

The growth of $P$. halotolerans was inhibited by BP3 from 100 to $4000 \mu \mathrm{g} \mathrm{L}{ }^{-1}$ (Fig. 2). The strain responded to BP3 in a non-monotonic manner with no difference between concentrations from 1000 to

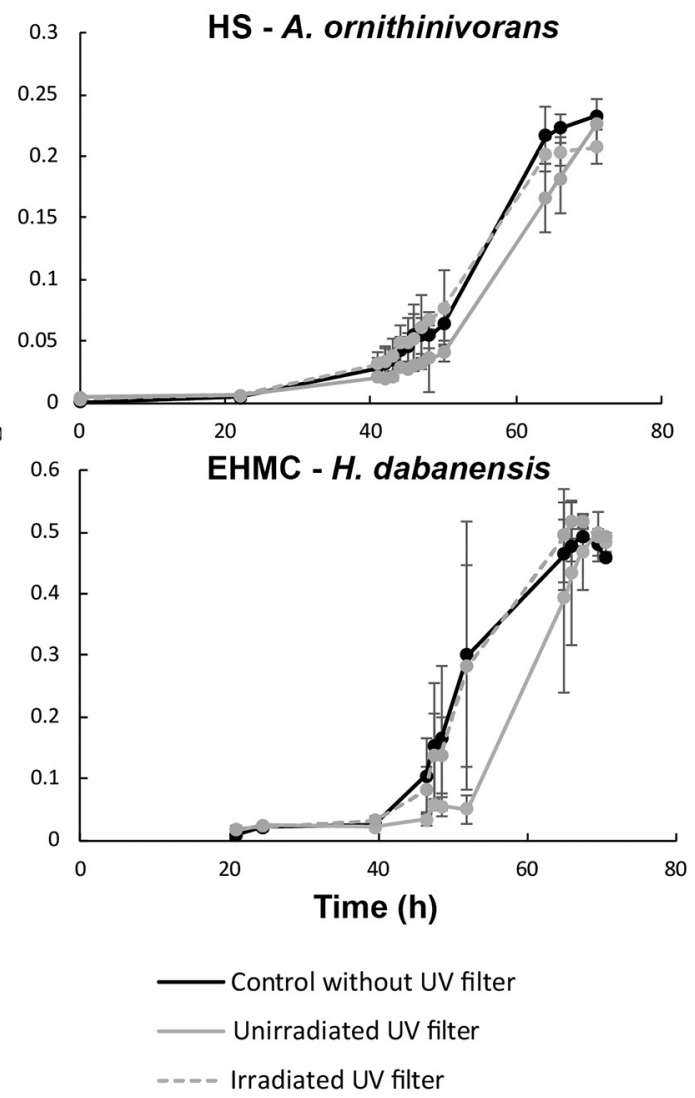

Fig. 5. Growth of bacterial strains in presence of irradiated or non-irradiated UV filters, expressed as optical density $(620 \mathrm{~nm}) \mathrm{mean} \pm \mathrm{standard}$ deviation. $(\mathrm{n}=3)$. 
$4000 \mu \mathrm{g} \mathrm{L}{ }^{-1}$. Similarly, non-monotonic effects were noticed for A. aurescens with $\mathrm{OC}$ as well as for D. maris and P. glucanolyticus with EHMC (Fig. 2). Interestingly, a non-monotonic effect was reported when assessing the toxicity of a biocide on Daphna magna (De Souza Machado et al., 2017). Indeed, the growth inhibition of D. magna was only observed for a given range of lower concentrations, as no effect was reported for the highest concentrations.

In contrast, A. ornithinivorans, $H$. dabanensis and $E$. mobile responded in a monotonic dose response manner to $\mathrm{HS}$ and $\mathrm{BP3}$, with $\mathrm{EC}_{50}$ of 772 , 1000 and $364 \mu \mathrm{g} \mathrm{L}^{-1}$, respectively (Fig. 3). The dose-response was found to be species and compound-dependent. Indeed, while BP3 exhibited a dose-dependent growth inhibition of E. mobile (BBCC 367), a nonmonotonic response was observed for P. halotolerans (BBCC 52) (Fig. 2), at similar concentrations than previously reported(Mao et al., 2017). BP3 and HS inhibited the growth of E. mobile and A. ornithinivorans, respectively, whereas HS only delayed the growth of $H$. dabdanensis, regardless of the concentration. It should be noted that the concentration of UV filters was not monitored throughout the experiments due to the inherent difficulties of measuring the concentration of UV filters in such a small volume.

Following the guidelines supported by the Regulation (EC) No 1907/ 2006 regarding the registration, evaluation, authorization and restriction of chemicals (REACH), we achieved environmental risk characterization. Predicted no effect concentration (PNEC), based on $\mathrm{EC}_{50}$ for $\mathrm{HS}$ and BP3, and on NOEC for EHMC, divided by arbitrarily defined constants (1000), are respectively 1000,364 and $200 \mathrm{ng} \mathrm{L}^{-1}$. Taking into account that these values were lower than the ones encountered in the environment (Kim and Choi, 2014; Tsui et al., 2014), a potential ecological risk should be considered.

\subsection{Combined effect of solar radiation and UV filters}

Previous studies demonstrated that UV filters could undergo photoinduced modifications that could alter their toxicity. BP3 displayed phototoxicity on human skin cells (Kim et al., 2018) and the UV-exposed EHMC showed an enhanced toxicity to Aliivibrio fischeri, Daphnia magna and Artemia salina (Gackowska et al., 2018). In this study, two strategies were used to investigate the combined effect of solar radiation and UV filters: (i) indirect effects: bacterial viability was monitored in the dark with UV filters previously exposed to solar radiation during 5 h (Figs. 4 and 5) (ii) direct effects: bacteria were simultaneously exposed to both solar radiation and UV filters (Figs. 6 and 7). In order to understand whether the cellular physiological state plays a role in the bacterial response, experiments were performed on bacteria harvested in stationary (Figs. 4 and 6) and exponential (Figs. 5 and 7) phases.

Regarding the indirect effects of solar radiation on the bacterial response, different patterns were observed depending on the bacterial growth phase. Viability of bacteria harvested in stationary phase was

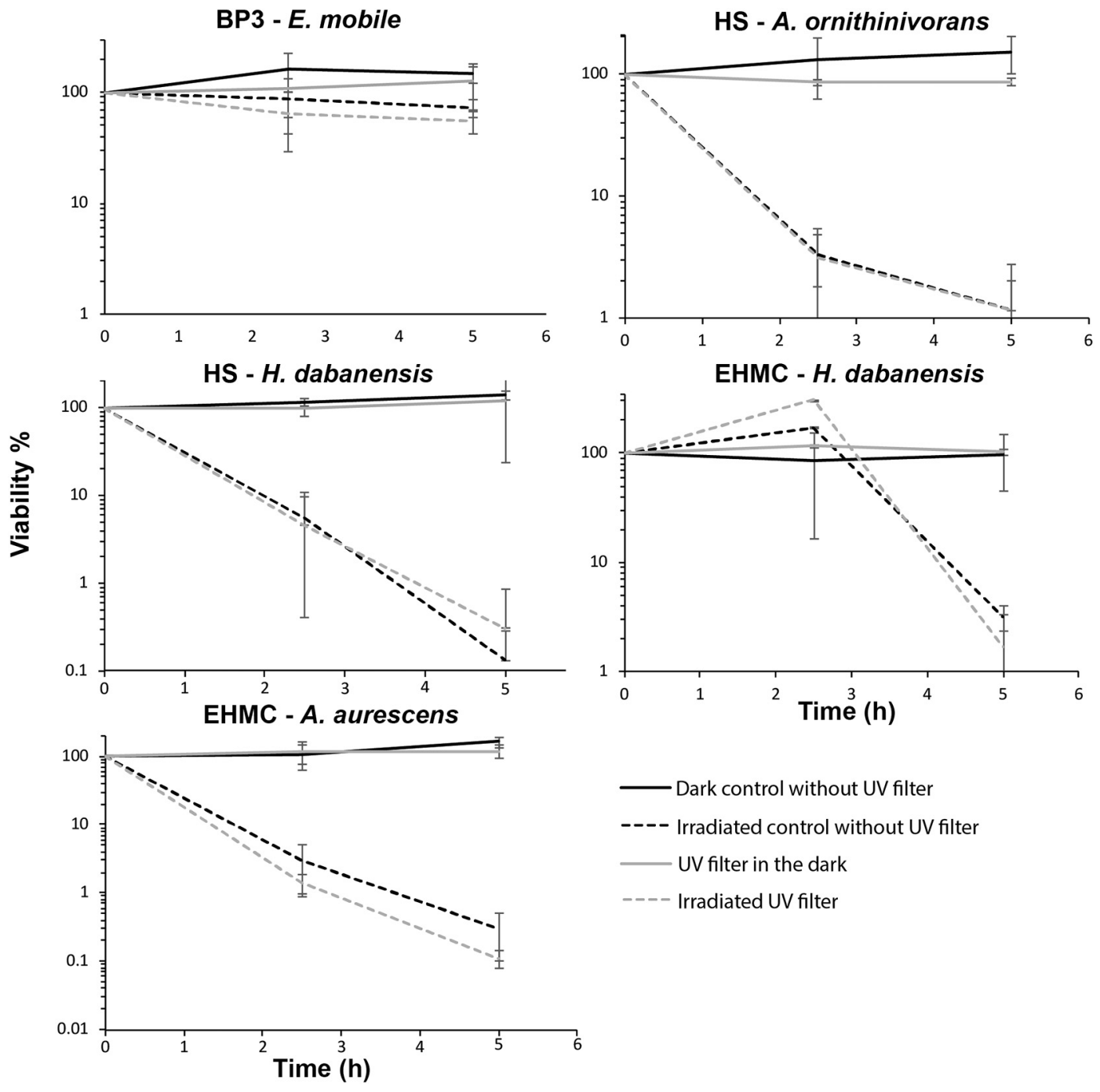

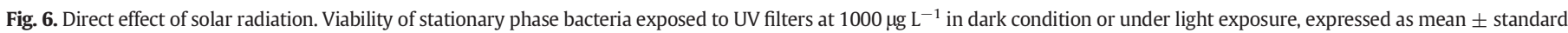
deviation. $(\mathrm{n}=3)$. 
not affected by pre-irradiated UV filters (Fig. 4). On the contrary, growing bacteria were found to be more impacted by the presence of UV filters (Fig. 5). The toxicity of BP3 was not altered by prior exposure to solar radiation (Figs. 4 and 5). In agreement with these results, former studies indicated high photostability of BP3 under artificial light exposure (Rodil et al., 2009; Liu et al., 2011). Pre-irradiation treatments of HS and EHMC were found to reduce their toxicity. Rodil and coworkers (2009) demonstrated that light exposure lowered the toxicity of EHMC on algal culture. To the best of our knowledge, the photostability of HS has never been reported. We provided evidence that its toxicity slightly decreased after exposure to solar radiation, suggesting a photodegradation of the parent compound. Irradiated EHMC was found to produce photoproducts resulting from degradation, isomerization, and dimerization reactions (Rodil et al., 2009; Jentzsch et al., 2016; MacManus-Spencer et al., 2011). In our study, irradiated EHMC did not present any enhanced toxicity in comparison to the non-irradiated molecule. It is noteworthy to emphasize that the viability of Hallobacillus dabanensis showed a 10 -fold increased after 24 h of exposure while the bacterial cells were suspended in glucose free ASW. This growth was consistently observed using a total of 6 replicates in independent experiments and this could be explained by spore forming characteristics of Halobacillus species (Liu et al., 2005). Interestingly, it was recently reported that under nutrient limitation, spore forming Bacillus subtilis would secrete extracellular factors that kill surrounding cells in order to feed on released nutrients (Gonzalez-Pastor et al., 2003). Hence, $H$. dabanensis might leave its stationary state and re-enter a growth phase by metabolizing nutrients from lysed cells. This consistent latter result needs to be further investigated.
Regarding the direct combined effect of solar radiation and UV filters on stationary phase cells, ANOVA post-hoc Tukey comparison showed no synergetic effect of both stresses on the loss of bacterial viability (Fig. 6). Solar radiation decreased viability of all studied species, except E. mobile, known as UVB resistant(Matallana-Surget et al., 2012).

Bacterial growth subjected to combined solar light and UV filters was monitored for $5 \mathrm{~h}$. Fold changes of optical density measured after and before the combined treatment $\left(\mathrm{OD}_{\mathrm{T} 5} / \mathrm{OD}_{\mathrm{T} 0}\right)$ were compared for each condition (Fig. 7). The toxicity of BP3 on E. mobile slightly increased with light exposure. However, no significant difference was observed between the control without BP3 exposed and the condition with BP3 exposed. EHMC displayed no enhanced phototoxicity on $H$. dabanensis. HS displayed greater toxicity on both $H$. dabanensis and A. ornithinivorans (Fig. 7), while pretreatment to solar radiation lowered its effect (Fig. 6). These observations emphasized that the effect of a compound can be enhanced by environmental parameters such as solar radiation.

Overall, our results suggest that bacteria in stationary phase were more resistant to UV filters than in exponential phase. Bacterial resistance in stationary phase was reported for a broad spectrum of antibiotics: fluoroquinolones, beta-lactams (Eng et al., 1991; Spoering and Lewis, 2001), or aminoglycosides (Greulich et al., 2015) that target DNA gyrase, penicillin binding proteins, and ribosomes, respectively. Bacteria entering stationary phase have evolved a well-regulated process allowing to cope with different stresses such as nutrient starvation, temperature change, acidic pH, UV damage or high osmolarity (Hengge, 2011). It was previously reported that the entry in stationary phase induced the expression of key transcription factors, such as stationary
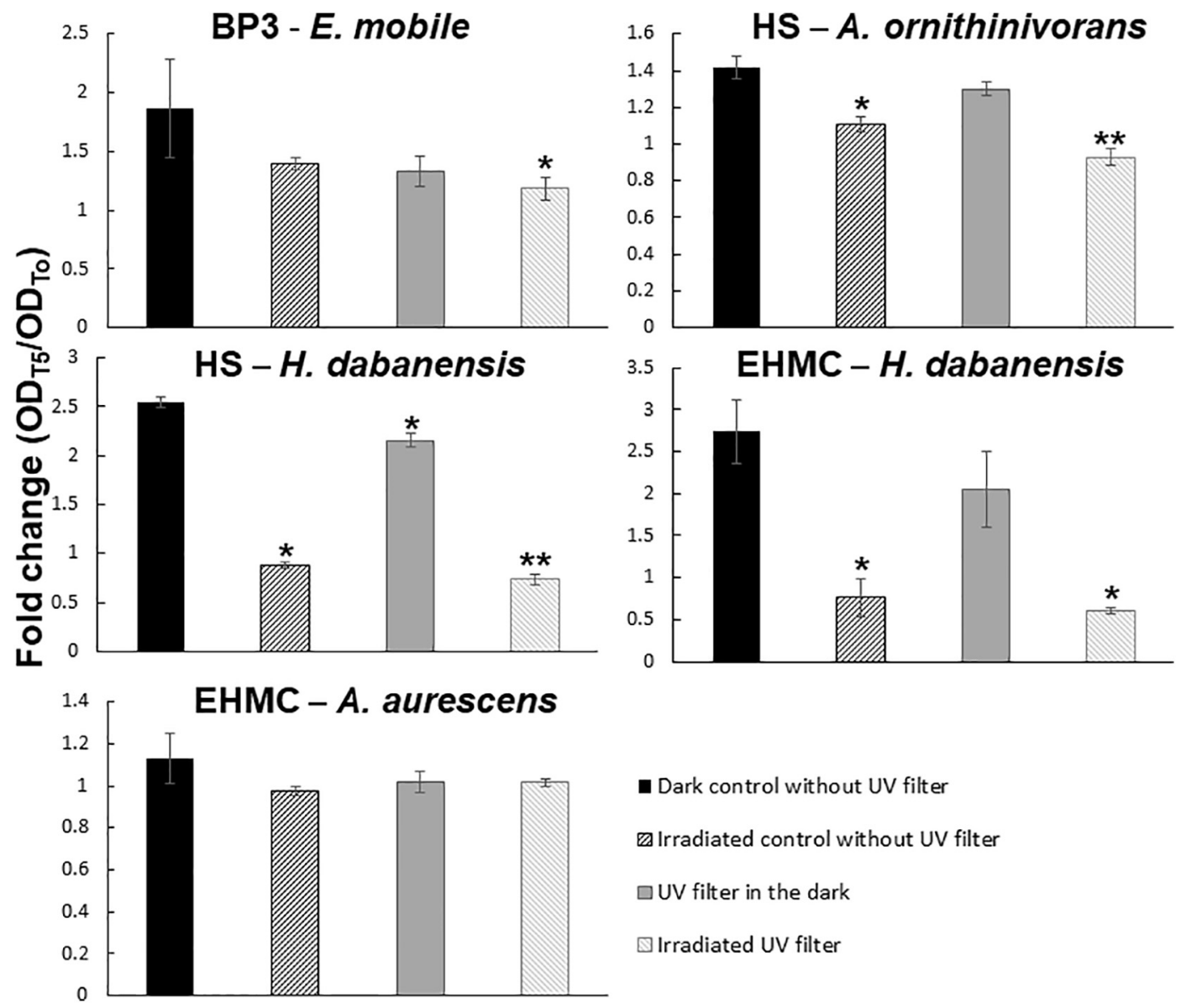

- Dark control without UV filter

Irradiated control without UV filter

$\square$ UV filter in the dark

Irradiated UV filter

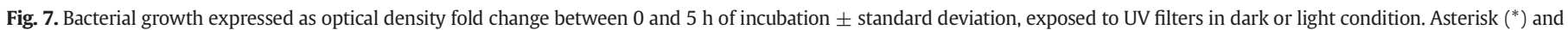
double asterisk $\left(^{* *}\right)$ highlight significant differences with the control without UV filter - dark, and exposed, respectively (ANOVA post-hoc Tukey's test $p<.05$ ). 
phase sigma factor in E. coli (Jaishankar and Srivastava, 2017) and Salmonella species (Testerman et al., 2002), leading to the resistance to multiple stressors.

\section{Conclusion}

This study is the first to assess the toxicity of UV filters on numerous heterotrophic marine bacteria. Our results demonstrated that $26 \%$ of all studied marine bacteria were sensitive to at least one organic UV filter commonly used in sunscreen products. HS toxicity was, for the first time, observed on a marine organism. BP3 was shown to exclusively affect gram negative while EHMC and HS impacted both gram positive and gram negative species. EHMC, also known as octinoxate, was the most toxic compound in our study, affecting five bacterial species. Phototoxicity analyses revealed a lower toxicity for HS and EHMC after pretreatment to solar radiation while combined exposure highlighted an increase in HS toxicity. None of the UV filters showed any toxicity at $1000 \mu \mathrm{g} \mathrm{L}^{-1}$ on stationary phase cells, demonstrating that physiological state is a key parameter in the bacterial response. In terms of environmental risk characterization, our results revealed that the increasing use of sun blockers could have detrimental impacts on bacterioplanktonic communities in coastal areas.

\section{CRediT authorship contribution statement}

Clément Lozano: Conceptualization, Methodology, Investigation, Writing - original draft. Sabine Matallana-Surget: Conceptualization, Methodology, Supervision, Writing - review \& editing, Funding acquisition. Justina Givens: Writing - review \& editing, Investigation. Salomé Nouet: Investigation. Louise Arbuckle: Investigation. Zacharie Lambert: Investigation. Philippe Lebaron: Conceptualization, Methodology, Supervision, Funding acquisition.

\section{Declaration of competing interest}

The authors declare that they have no known competing financial interests or personal relationships that could have appeared to influence the work reported in this paper.

\section{Acknowledgment}

Clément Lozano is the recipient of a 50/50 match funding scholarship between the University of Stirling (Scotland, United Kingdom) and the University of Sorbonne (France). We thank bio2mar platform (http://bio2mar.obs-banyuls.fr) for technical assistance and access to equipment. This work was supported by the Carnegie Research Incentive Grant (RIG008612). The funders had no role in study design, data collection and analysis, or decision to publish.

\section{References}

Alonso, M.B., Feo, M.L., Corcellas, C., Gago-Ferrero, P., Bertozzi, C.P., Marigo, J., Flach, L., Meirelles, A.C.O., Carvalho, V.L., Azevedo, A.F., et al., 2015. Toxic heritage: maternal transfer of pyrethroid insecticides and sunscreen agents in dolphins from Brazil. Environ. Pollut. 207, 391-402. https://doi.org/10.1016/j.envpol.2015.09.039.

Apel, C., Tang, J., Ebinghaus, R., 2018. Environmental occurrence and distribution of organic UV stabilizers and UV filters in the sediment of European north and Baltic seas. Environ. Pollut. 235, 85-94. https://doi.org/10.1016/j.envpol.2017.12.051.

Araújo, M.J., Rocha, R.J.M., Soares, A.M.V.M., Benedé, J.L., Chisvert, A., Monteiro, M.S., 2018. Effects of UV filter 4-methylbenzylidene camphor during early development of Soled Senegalensis. Sci. Total Environ. 628-629, 1395-1404. https://doi.org/10.1016/j. scitotenv.2018.02.112.

Azam, F., Malfatti, F., 2007. Microbial structuring of marine ecosystems. Nat. Rev. Microbiol. 5 (10), 782-791. https://doi.org/10.1038/nrmicro1747.

Balasubramanian, V., Natarajan, K., Hemambika, B., Ramesh, N., Sumathi, C.S., Kottaimuthu, R., Rajesh Kannan, V., 2010. High-Density Polyethylene (HDPE)degrading potential bacteria from marine ecosystem of Gulf of Mannar, India. Lett. Appl. Microbiol. 51 (2), 205-211. https://doi.org/10.1111/j.1472-765X.2010.02883.X.
Balmer, M.E., Buser, H.R., Müller, M.D., Poiger, T., 2005. Occurrence of some organic UV filters in wastewater, in surface waters, and in fish from Swiss Lakes. Environ. Sci. Technol. 39 (4), 953-962. https://doi.org/10.1021/es040055r.

Bar-On, Y.M., Phillips, R., Milo, R., 2018. The biomass distribution on earth. Proc. Natl. Acad. Sci. U. S. A. 115 (25), 6506-6511. https://doi.org/10.1073/pnas.1711842115.

Buchan, A., Moran, M.A., 2005. MINIREVIEW Overview of the Marine Roseobacter Lineage †. 71 (10), pp. 5665-5677.. https://doi.org/10.1128/AEM.71.10.5665.

Campos, D. Gravato, C., Fedorova, G. Burkina, V., Soares, A.M.V.M., Joao, L T.P. 2017. Ecotoxicity of two organic UV-filters to the freshwater caddis Fly Sericostoma Vittatum. Environ. Pollut. 228, 370-377. https://doi.org/10.1016/j envpol.2017.05.021.

Coclet, C., Garnier, C., Durrieu, G., Omanović, D., D’Onofrio, S., Le Poupon, C., Mullot, J.-U., Briand, J.-F., Misson, B., 2019. Changes in bacterioplankton communities resulting from direct and indirect interactions with trace metal gradients in an urbanized marine coastal area. Front. Microbiol. 10. https://doi.org/10.3389/fmicb.2019.00257.

Damiani, E., Astolfi, P., Giesinger, J., Ehlis, T., Herzog, B., Greci, L., Baschong, W., 2010. Assessment of the photo-degradation of UV-filters and radical-induced peroxidation in cosmetic sunscreen formulations. Free Radic. Res. 44 (3), 304-312. https://doi.org/ $10.3109 / 10715760903486065$.

De Souza Machado, A.A., Zarfl, C., Rehse, S., Kloas, W., 2017. Low-dose effects: nonmonotonic responses for the toxicity of a Bacillus Thuringiensis biocide to Daphnia Magna. Environ. Sci. Technol. 51 (3), 1679-1686. https://doi.org/10.1021/acs. est.6b03056.

Downs, C.A., Kramarsky-Winter, E., Segal, R., Fauth, J., Knutson, S., Bronstein, O., Ciner, F.R. Jeger, R., Lichtenfeld, Y., Woodley, C.M., et al., 2016. Toxicopathological effects of the sunscreen UV filter, oxybenzone (benzophenone-3), on coral Planulae and cultured primary cells and its environmental contamination in Hawaii and the U.S. Virgin Islands. Arch. Environ. Contam. Toxicol. 70 (2), 265-288. https://doi.org/10.1007/ s00244-015-0227-7.

Egan, S., Harder, T., Burke, C., Steinberg, P., Kjelleberg, S., Thomas, T., 2013. The seaweed holobiont: understanding seaweed-bacteria interactions. FEMS Microbiol. Rev. 37 (3), 462-476. https://doi.org/10.1111/1574-6976.12011.

Eguchi, M., Nishikawa, T., Macdonald, K., Cavicchioli, R., Gottschal, J.C., Kjelleberg, S., 1996. Responses to Stress and nutrient availability by the marine ultramicrobacterium sphingomonas Sp. Strain RB2256. Appl. Environ. Microbiol. 62 (4), 1287-1294.

Eng, R.H.K., Padberg, F.T., Smith, S.M., Tan, E.N., Cherubin, C.E., 1991. Bactericidal effects of antibiotics. Antimicrob. Agents Chemother. 35 (9), 1824-1828. https://doi.org/ 10.1128/AAC.35.9.1824.Updated.

Fagervold, S.K., Rodrigues, A.S., Rohée, C., Roe, R., Bourrain, M., Stien, D., Lebaron, P., 2019 Occurrence and environmental distribution of 5 UV filters during the summer season in different water bodies. Water Air Soil Pollut. 3 (230), 172. https://doi.org/10.1007/ s11270-019-4217-7.

Fent, K., Zenker, A., Rapp, M., 2010. Widespread occurrence of estrogenic UV-filters in aquatic ecosystems in Switzerland. Environ. Pollut. 158 (5), 1817-1824. https://doi. org/10.1016/j.envpol.2009.11.005.

Gackowska, A., Studziński, W., Kudlek, E., Dudziak, M., Gaca, J., 2018. Estimation of physicochemical properties of 2-ethylhexyl-4-methoxycinnamate (EHMC) degradation products and their toxicological evaluation. Environ. Sci. Pollut. Res., 1-13 https:// doi.org/10.1007/s11356-018-1796-6.

Gago-Ferrero, P., Alonso, M.B., Bertozzi, C.P., Marigo, J., Barbosa, L., Cremer, M., Secchi, E.R., Azevedo, A., Lailson-Brito, J., Torres, J.P.M., et al., 2013. First determination of UV filters in marine mammals. Octocrylene levels in Franciscana dolphins. Environ. Sci. Technol. 47 (11), 5619-5625. https://doi.org/10.1021/es400675y.

Giraldo, A., 2017. Ecotoxicological Evaluation of the UV Filters Ethylhexyl Dimethyl P -Aminobenzoic Acid and Octocrylene Using Marine Organisms Isochrysis Galbana Mytilus Galloprovincialis and Paracentrotus Lividus. , pp. 606-611. https://doi.org/ 10.1007/s00244-017-0399-4.

Gonzalez-Pastor, J.E., Hobbs, E.C., Losick, R., 2003. Cannibalism by sporulating bacteria. Science (80) 301 (July), 510-513. https://doi.org/10.1126/science.1086462.

Greulich, P., Scott, M., Evans, M.R., Allen, R.J., 2015. Growth-dependent bacterial susceptibility to ribosome-targeting antibiotics. Mol. Syst. Biol. 11 (3), 796. https://doi.org/ 10.15252/msb.20145949.

He, T., Tsui, M.M.P., Tan, C.J., Ng, K.Y., Guo, F.W., Wang, L.H., Chen, T.H., Fan, T.Y., Lam, P.K.S., Murphy, M.B., 2019. Comparative toxicities of four benzophenone ultraviolet filters to two life stages of two coral species. Sci. Total Environ. 651, 2391-2399. https://doi.org/10.1016/j.scitotenv.2018.10.148.

Hengge, R., 2011. Stationary-phase gene regulation in Escherichia Coli. Am. Soc. Microbiol. (4) https://doi.org/10.1128/ecosalplus.5.6.3.

Herzog, B., Wehrle, M., Quass, K., 2009. Photostability of UV absorber systems in sunscreens. Photochem. Photobiol. 85 (4), 869-878. https://doi.org/10.1111/j.17511097.2009.00544.x.

Jaishankar, J., Srivastava, P., 2017. Molecular basis of stationary phase survival and applications. Front. Microbiol. 8 (OCT), 1-12. https://doi.org/10.3389/ fmicb.2017.02000.

Jentzsch, F., Olsson, O., Westphal, J., Reich, M., Leder, C., Kümmerer, K., 2016 Photodegradation of the UV filter ethylhexyl methoxycinnamate under ultraviolet light: identification and in Silico assessment of photo-transformation products in the context of grey water reuse. Sci. Total Environ. 572, 1092-1100. https://doi.org/ 10.1016/j.scitotenv.2016.08.017.

Kameda, Y., Kimura, K., Miyazaki, M., 2011. Occurrence and profiles of organic sunblocking agents in surface waters and sediments in Japanese Rivers and lakes. Environ. Pollut. 159 (6), 1570-1576. https://doi.org/10.1016/j.envpol.2011.02.055.

Kim, H.J., Lee, E., Lee, M., Ahn, S., Kim, J., Liu, J., Jin, S.H., Ha, J., Bae, I.H., Lee, T.R., et al., 2018. Phosphodiesterase 4B plays a role in Benzophenone-3-induced Phototoxicity in Normal human keratinocytes. Toxicol. Appl. Pharmacol. 338 (November 2017), 174-181. https://doi.org/10.1016/j.taap.2017.11.021. 
Kim, S., Choi, K., 2014. Occurrences, toxicities, and ecological risks of benzophenone-3, a common component of organic sunscreen products: a mini-review. Environ. Int. 70, 143-157. https://doi.org/10.1016/j.envint.2014.05.015.

Kundu, K., Marozava, S., Ehrl, B., Merl-Pham, J., Griebler, C., Elsner, M., 2019. Defining lower limits of biodegradation: atrazine degradation regulated by mass transfer and maintenance demand in Arthrobacter Aurescens TC1. ISME J, 2236-2251 https://doi.org/10.1038/s41396-019-0430-z.

Langford, K.H., Reid, M.J., Fjeld, E., Øxnevad, S., Thomas, K.V., 2015. Environmental occurrence and risk of organic UV filters and stabilizers in multiple matrices in Norway. Environ. Int. 80, 1-7. https://doi.org/10.1016/j.envint.2015.03.012.

Lee, Y.K., Lee, J.-H., Lee, H.K., 2001. Microbial Symbiosis in marine sponges. J. Microbiol. 39 (4), 254-264.

Lewin, C.S., Howard, B.M.A., Smith, J.T., 1991. Protein- and RNA-Synthesis Independent Bactericidal Activity of Ciprofloxacin that Involves the A Subunit of DNA Gyrase. 34 pp. 19-22.

Li, Y.; Yang, N.; Liang, X.; Yoshida, A.; Osatomi, K.; Power, D.; M. Batista, F.; Yang, J.-L. Elevated seawater temperatures decrease microbial diversity in the gut of Mytilus Coruscus. Front. Physiol. 2018, 9 (July), 1-9. doi:https://doi.org/10.3389/ fphys.2018.00839.

Liu, H., Sun, P., Liu, H., Yang, S., Wang, L., Wang, Z., 2015. Acute toxicity of benzophenonetype UV filters for Photobacterium Phosphoreum and Daphnia Magna: QSAR analysis, interspecies relationship and integrated assessment. Chemosphere 135, 182-188. https://doi.org/10.1016/j.chemosphere.2015.04.036.

Liu, W.Y., Zeng, J., Wang, L., Dou, Y.T., Yang, S.S., 2005. Halobacillus Dabanensis Sp. Nov: and Halobacillus Aidingensis Sp. Nov., isolated from Salt Lakes in Xinjiang, China. Int. J. Syst. Evol. Microbiol. 55 (5), 1991-1996. https://doi.org/10.1099/ijs.0.63787-0.

Liu, Y.S., Ying, G.G., Shareef, A., Kookana, R.S., 2011. Photostability of the UV filter benzophenone-3 and its effect on the Photodegradation of Benzotriazole in water Environ. Chem. 8 (6), 581-588. https://doi.org/10.1071/EN11068.

MacManus-Spencer, L.A., Tse, M.L., Klein, J.L., Kracunas, A.E., 2011. Aqueous photolysis of the organic ultraviolet filter chemical octyl methoxycinnamate. Environ. Sci. Technol. 45 (9), 3931-3937. https://doi.org/10.1021/es103682a.

Mao, F., He, Y., Kushmaro, A., Gin, K.Y.H., 2017. Effects of Benzophenone-3 on the green alga Chlamydomonas Reinhardtii and the Cyanobacterium Microcystis Aeruginosa. Aquat. Toxicol. 193 (September), 1-8. https://doi.org/10.1016/j.aquatox.2017.09.029.

Mao, F., Yiliand, H., Karina, Y.-H.G., 2018. Evaluating the joint toxicity of two benzophenone-type UV filters on the green alga Chlamydomonas Reinhardtii with response surface methodology. MDPI (1), 1-12 https://doi.org/10.3390/toxics6010008.

Matallana-Surget, S., Villette, C., Intertaglia, L., Joux, F., Bourrain, M., Lebaron, P., 2012. Response to UVB radiation and oxidative stress of marine bacteria isolated from South Pacific Ocean and Mediterranean Sea. J. Photochem. Photobiol. B Biol. 117, 254-261. https://doi.org/10.1016/j.jphotobiol.2012.09.011.

Mitchelmore, C.L., He, K., Gonsior, M., Hain, E., Heyes, A., Clark, C. Younger, R., SchmittKopplin, P., Feerick, A., Conway, A., et al., 2019. Occurrence and distribution of UV filters and other anthropogenic contaminants in coastal surface water, sediment, and coral tissue from Hawaii. Sci. Total Environ. 670, 398-410. https://doi.org/ 10.1016/j.scitotenv.2019.03.034.

Müller, A., Wenzel, M., Strahl, H., Grein, F., Saaki, T.N.V., Kohl, B., Siersma, T., Bandow, J.E., Sahl, H.G., Schneider, T., et al., 2016. Daptomycin inhibits cell envelope synthesis by interfering with fluid membrane microdomains. Proc. Natl. Acad. Sci. U. S. A. 113 (45), E7077-E7086. https://doi.org/10.1073/pnas.1611173113.

M. C. Pelletier, Robert M. Burgess, K. T. Ho, A. Kuhn, R.A.M. and S.A.R. Phototoxicity of Individual Polycyclic Aromatic Hydrocarbons and Petroleum to Marine Invertebrate Larvae and Juveniles. 1997, vol. 16 (10), 2190-2199.

Petersen, D.G., Reichenberg, F., Dahllöf, I., 2008. Phototoxicity of Pyrene affects benthic algae and bacteria from the Arctic. Environ. Sci. Technol. 42 (4), 1371-1376. https://doi.org/10.1021/es071854n.

Ramanan, R., Kim, B.H., Cho, D.H., Oh, H.M., Kim, H.S., 2016. Algae-bacteria interactions: evolution, ecology and emerging applications. Biotechnol. Adv. 34 (1), 14-29. https://doi.org/10.1016/j.biotechadv.2015.12.003.

Reshef, L., Koren, O., Loya, Y., Zilber-Rosenberg, I., Rosenberg, E., 2006. The coral probiotic hypothesis. Environ. Microbiol. 8 (12), 2068-2073. https://doi.org/10.1111/j.14622920.2006.01148.x.

Rodil, R., Moeder, M., Altenburger, R., Schmitt-Jansen, M., 2009. Photostability and phytotoxicity of selected sunscreen agents and their degradation mixtures in water. Anal. Bioanal. Chem. 395 (5), 1513-1524. https://doi.org/10.1007/s00216-009-3113-1.
Rainieri, S., Barranco, A., Primec, M., Langerholc, T., 2017. Occurrence and toxicity of musks and UV filters in the marine environment. Food Chem. Toxicol 104, 57-68. https://doi.org/10.1016/j.fct.2016.11.012.

Sakkas, V.A., Calza, P., Islam, M.A., Medana, C., Baiocchi, C., Panagiotou, K., Albanis, T., 2009. TiO2/H2O2-mediated Photocatalytic transformation of UV filter 4Methylbenzylidene camphor (4-MBC) in aqueous phase: statistical optimization and photoproduct analysis. Appl. Catal. B Environ. 90 (3-4), 526-534. https://doi. org/10.1016/j.apcatb.2009.04.013.

Sánchez Rodríguez, A., Rodrigo Sanz, M., Betancort Rodríguez, J.R., 2015. Occurrence of eight UV filters in beaches of Gran Canaria (Canary Islands). An approach to environmental risk assessment. Chemosphere 131, 85-90. https://doi.org/10.1016/j. chemosphere.2015.02.054

Sankoda, K., Murata, K., Tanihata, M., Suzuki, K., Nomiyama, K., Shinohara, R., 2015. Seasonal and diurnal variation of organic ultraviolet filters from personal care products used along the Japanese coast. Arch. Environ. Contam. Toxicol. 68 (2), 217-224. https://doi.org/10.1007/s00244-014-0106-7.

Sawulski, P., Clipson, N., Doyle, E., 2014. Effects of polycyclic aromatic hydrocarbons on microbial community structure and $\mathrm{PAH}$ ring hydroxylating dioxygenase gene abundance in soil. Biodegradation 25 (6), 835-847. https://doi.org/10.1007/s10532-0149703-4.

Seoane, M., Esperanza, M., Rioboo, C., Herrero, C., Cid, Á., 2017. Flow cytometric assay to assess short-term effects of personal care products on the marine microalga Tetraselmis Suecica. Chemosphere 171, 339-347. https://doi.org/10.1016/j. chemosphere.2016.12.097.

Shaath, N.A., 2010. Ultraviolet filters. Photochem. Photobiol. Sci. 9 (4), 464. https://doi. org/10.1039/b9pp00174c

Sieratowicz, A., Kaiser, D., Behr, M., Oetken, M., Oehlmann, J., 2011. Acute and chronic toxicity of four frequently used UV filter substances for Desmodesmus Subspicatus and Daphnia Magna. J. Environ. Sci. Heal. - Part A Toxic/Hazardous Subst. Environ. Eng. 46 (12), 1311-1319. https://doi.org/10.1080/10934529.2011.602936.

Spoering, A., Lewis, K., 2001. Biofilms and planktonic cells of Pseudomonas Aeruginosa have similar resistance to killing by antimicrobials. J. Bacteriol. 183 (23), 6746-6751. https://doi.org/10.1128/JB.183.23.6746.

Testerman, T.L., Vazquez-torres, A., Xu, Y., Jones-carson, J., Libby, S.J., Fang, F.C., 2002. The alternative sigma factor controls antioxidant defences required for Salmonella virulence and stationary-phase survival. Mol. Microbiol. 43 (3), 771-782. https://doi. org/10.1046/j.1365-2958.2002.02787.x.

Torres, T., Cunha, I., Martins, R., Santos, M.M., 2016. Screening the toxicity of selected personal care products using embryo bioassays: 4-MBC, Propylparaben and Triclocarban. Int. J. Mol. Sci. 17 (10). https://doi.org/10.3390/ijms17101762.

Tovar-Sánchez, A., Sánchez-Quiles, D., Basterretxea, G., Benedé, J.L., Chisvert, A., Salvador, A., Moreno-Garrido, I., Blasco, J., 2013. Sunscreen products as emerging pollutants to coastal waters. PLoS One 8 (6). https://doi.org/10.1371/journal.pone.0065451.

Tsui, M.M.P., Leung, H.W., Wai, T.C., Yamashita, N., Taniyasu, S., Liu, W., Lam, P.K.S., Murphy, M.B., 2014. Occurrence, distribution and ecological risk assessment of multiple classes of UV filters in surface waters from different countries. Water Res. 67, 55-65. https://doi.org/10.1016/j.watres.2014.09.013.

Tsui, M.M.P., Lam, J.C.W., Ng, T.Y., Ang, P.O., Murphy, M.B., Lam, P.K.S., 2017. Occurrence, distribution, and fate of organic UV filters in coral communities. Environ. Sci. Technol. 51 (8), 4182-4190. https://doi.org/10.1021/acs.est.6b05211.

Tsui, M.M.P., Chen, L., He, T., Wang, Q., Hu, C., Lam, J.C.W., Lam, P.K.S., 2019. Organic ultraviolet (UV) filters in the South China Sea coastal region: environmental occurrence, toxicological effects and risk assessment. Ecotoxicol. Environ. Saf. 181 (March), 26-33. https://doi.org/10.1016/j.ecoenv.2019.05.075.

Whitman, W.B., Coleman, D.C., Wiebe, W.J., 1998. Prokaryotes: the unseen majority. Proc. Natl. Acad. Sci. 95 (12), 6578-6583. https://doi.org/10.1073/pnas.95.12.6578.

Yilmaz, P., Yarza, P., Rapp, J.Z., Glöckner, F.O., 2016. Expanding the world of marine bacterial and Archaeal clades. Front. Microbiol. 6 (JAN), 1-29. https://doi.org/10.3389/ fmicb.2015.01524

Zhang, Q., Ma, X., Dzakpasu, M., Wang, X.C., 2017. Evaluation of Ecotoxicological effects of Benzophenone UV filters: luminescent bacteria toxicity, Genotoxicity and hormonal activity. Ecotoxicol. Environ. Saf. 142 (April), 338-347. https://doi.org/10.1016/j. ecoenv.2017.04.027 